\title{
Öğretmenlere ve Okul Yöneticilerine Verilen Hizmet İçi Eğitimlerin İrdelenmesi *
}

\section{Özet}

Ali Rıza ERDEM ** Selçuk ŞIMŞEK ***

Hizmet içi eğitim yaşam boyu eğitimi de içine alan bir süreçtir. Öğretmenlere yönelik hizmet içi eğitim; eğitimde amaçlanan niteliklerin öğrencilere kazandırılması için gerekli bilgi, beceri, tutum ve alışkanlıklar ile bilimsel ve sosyo-ekonomik gerçekler ışığında eksikliği kanıtlanan mesleki bilgi, beceri, tutum ve alışkanlıkların öğretmenlere kazandırılmasını hedefleyen süreçlerin bütünü olarak tanımlanabilir. $\mathrm{Bu}$ çalışmada okulöncesi, ilköğretim, ortaöğretim okul yöneticileri ve bu okullarda görev yapan öğretmenlere verilen hizmetiçi eğitim irdelenmiştir. Denizli İl Milli Eğitim Müdürlüğünün gerçekleştirdiği hizmetiçi eğitim etkinlikleri ve etkinliklere katılan okulöncesi, ilköğretim, ortaöğretim okul yöneticileri ve bu okullarda görev yapan öğretmenlerle ilgili veriler Denizli İl Milli Eğitim Müdürlüğü Hizmetiçi Eğitim biriminden elde edilmiştir. Çalışmayla ilgili elde edilen sonuçlar incelendiğinde, Denizli İl Milli Eğitim Müdürlügünün 2011-2012 eğitim-öğretim yılında okulöncesi, ilköğretim, ortaöğretim okul yöneticileri ve bu okullarda görev yapan öğretmenlere yönelik planlanan hizmetiçi eğitim etkinliklerinin \% 63'ü gerçekleştirilmiş

Anahtar Kelimeler: Milli Eğitim Bakanlığı, Denizli İl Milli Eğitim Müdürlüğü Öğretmen, Okul Yöneticileri, Hizmet İçi Eğitim,

\section{Investigating In-Service Training Given to Teachers and School Heads}

\author{
Abstract \\ In-service training is a process covering lifelong education. In- \\ service teaching training includes a whole training process in which

\footnotetext{
* Bu çalı̧̧ma, 20-22 Eylül 2012 tarihlerinde "I. Uluslararası Katılımlı Öğretmen Yetiştirme ve Geliştirme Sempozyumu" nda sözlü bildiri olarak sunulmuştur.

** Doç. Dr., Pamukkale Üniversitesi, Eğitim Fakültesi, E-mail: arerdem@pau.edu.tr

*** Yrd. Doç. Dr., Pamukkale Üniversitesi, Eğitim Fakültesi, E-mail: selcuks@pau.edu.tr
} 
knowledge, skills, attitudes and practices needed to help students to gain the qualities aimed in education and professional knowledge, skills, attitudes and practices proven the deficiencies by scientific and socio-economic rights are given. This study investigated in-service training given to teachers and school heads at preschool education to secondary education. The data used in this study was gathered from Denizli Directory of National Education Inservice Training Department. The data included the in-service teaching training programs and teachers and schools heads attended those programs. The results showed that in-service training activities designed for directors and teachers at pre-schools, primary schools and secondary schools in 2012012 education term were done at level $63 \%$.

Keywords: Ministry of national education, Denizli directory of national education, teacher, school heads, in-service training,

\section{Giriş}

Hizmetiçi eğitimde genel ilke hizmet öncesi eğitimin kişinin meslek hayatı boyunca asla yeterli olmadığıdır. Mevcut bilgi birikiminin katlanarak arttığı günümüzde, bireylerin, bilgi ve teknolojideki gelişmelere bağlı olarak toplumun kültürel, sosyal ve ekonomik yapısında meydana gelen değişme ve gelişmelere uyum sağlayabilmeleri ancak, yasam boyu eğitim görmeleri ile mümkündür. Hizmet içi eğitim yaşam boyu eğitimi de içine alan bir süreçtir. Yasam boyu eğitimin bir gerçeği olarak hizmetiçi eğitim, çalışanlara mesleklerinde daha başarılı, üretici ve mutlu olmasını sağlayacak bilgi, beceri ve tutumlar kazandırmayı amaçlamaktadır. Çünkü iyi eğitilen personel iyi is veya hizmet üretir. Diğer bir ifade ile, verimlilik ve etkinliğin sağlanmasında hizmet içi eğitimin önemi büyüktür. Başlıca hizmetiçi eğitim türleri, sosyalleștirme eğitimi, değişikliklere uyum eğitimi, bilgi tazeleme eğitimi ve üst düzey görevlere hazırlama eğitimi olarak sınıflandırılabilir. (Yüksel, 1998; Yalın, 2001; Gökbulut, 2006; Yıldırım, 2007; Arseven, 2009; Can, 2011).

Yine teknolojinin hızlı gelişmesi, uzmanlaşmaya eğilim, eğitimin belirli sürelerle ve programlarla sınırlandırılmasını güçleştirmekte, sürekli eğitimi zorunlu hale getirmektedir. Yaşanan hızlı değişim ve gelişmeler; insan yaşamını çeşitli açılardan etkilemekte ve sosyal kurumların yapı ve fonksiyonlarını değişime zorlamaktadır. Bu değişimlere ayak uydurma çabası yenilikleri takip etme olanağı sağlayan ve gelişmelere açık bir eğitim sisteminin oluşturulmasını kaçınılmaz kılmaktadır. Eğitim kurumları 
değişime ayak uydurma ve kendini sürekli yenileme durumundadır. Bu süreçte öğretmenlerin oynayacakları rol büyük önem taşımaktadır. Çünkü bir okulun kalitesi öğretmenlerinin sunacağı eğitim hizmetinin kalitesine bağlıdır. Öğretmenlerin bunu başarabilmeleri için hem hizmet öncesinde iyi yetiştirilmeleri, hem de hizmet içinde kendilerini sürekli geliştirmeleri gerekir. Öğretmenlere yönelik hizmet içi eğitim; eğitimde amaçlanan niteliklerin öğrencilere kazandırılması için gerekli bilgi, beceri, tutum ve alışkanlıklar ile bilimsel ve sosyo-ekonomik gerçekler ışığında eksikliği kanıtlanan mesleki bilgi, beceri, tutum ve alışkanlıkların öğretmenlere kazandırılmasını hedefleyen süreçlerin bütünü olarak tanımlanabilir (Erişen, 1998; Budak, 1998; Taş̧̧1, 2003; Seferoğlu, 2005; Uçar \& İpek, 2006).

Öğretmenlerinin devamlı olarak kendini yenilemeleri, yetiştirmeleri kısacası profesyonel bir öğretmen kimliği kazanmaları gerekir. Öğretmenlerin niteliklerinin gelişmesi ve profesyonel bir kimlik kazanmaları sadece hizmet öncesi eğitim ile değil hizmet öncesi ve hizmet içi eğitim süreçlerinin bütünleşmesi ile mümkün olabilir. Öğretmenlerin mesleklerindeki gelişmeleri takip edebilmeleri, gelişen teknoloji ve araçlara uyum sağlayabilmeleri yani gerekli olan mesleki bilgi ve becerileri kazanmaları hizmetiçi eğitim faaliyetleriyle sağlanacaktır. Hizmet içi eğitim yoluyla öğretmenlerin göreve başladıkları okula uyumlarının sağlanması, kalite için okul içinde işbirliği; kurum içerisinde rekabet ortamının oluşturulması, eğitimde bütünlüğün sağlanması ve göreve henüz başlayan öğretmenlere iletişim ve teknik becerilerin kazandırılması sağlanmalıdır (Karaküçük, 1987; Saban, 2000; Azar \& Karaali, 2004; Çatmalı, 2006; Aydın, 2008) .

Gelişmiş ülkeler öğretmenlerin hizmetiçi eğitimine büyük önem vermektedir. Almanya'da tüm öğretmenler her eyalette eğitim bakanlığına bağlı olarak kurulan hizmetiçi eğitim enstitüsü tarafından düzenli olarak verilen hizmetiçi eğitime katılmak zorundadırlar. ABD'de öğretmenlerin hizmetiçi eğitim programlarına katılması, mesleğinde kendini yenilemesi genellikle tüm eyaletlerde yasal bir zorunluluktur. Bununla beraber her eyalet kendi şartları içinde çeşitli projeler planlayarak öğretmenleri daha bilgili, daha verimli kısaca daha iyi duruma getirmek için çaba sarf etmektedir. Fransa'da her öğretmen meslek yasamı boyunca en az 36 haftalık hizmetiçi eğitim kurslarına katılmak zorundadır. Öğretmenlerin hizmetiçi eğitim kurslarının düzenlenmesinde, program içeriğinin belirlenmesinde, öğretmenlerin seçilmesinde, programın yürütülmesinde, sınav biçimlerinin, diploma, sertifika türlerinin belirlenmesinde öğretmen 
sendikası etkin rol oynar. Öğretmenlerin bu kurslarda aldıkları sertifikalar ve dereceleri terfi ve atanmalarında önemli belirleyiciler arasında yer alır. Başarısızlık ve kurslara katılmama ise öğretmenlere olumsuz puanlar getirir. İngiltere'de hizmetiçi eğitim öğretmenlerin mesleki yeterliliklerini korumalarını ve değişen rollerini gerçekleştirmek için yeni beceriler elde etmelerine olanak tanır. Bu yolla öğretmenlerin kişisel gelişimleri desteklenir. İngiltere'de, hizmetiçi eğitim değişik kurumlar aracılığı ile yapılmaktadır. Özellikle öğretim yılı içerisinde düzenlenen programlarda üniversiteler, bölge eğitim yetkilileri ve okullar görev almaktadırlar. Japonya'da hizmetiçi eğitim faaliyetleri eğitim merkezlerinde verilmektedir. Bu eğitim merkezlerinde tam zamanlı olarak çalışan görevlilerin yanı sıra, seçilmiş üniversite profesörleri ve bazı kaynak kişiler (bilirkişiler, endüstri yöneticileri, misafir konuşmacılar) eğitim vermektedirler. Avusturya'da hizmetiçi eğitim kursları enstitülerde düzenlenmektedir. Bu enstitülerin çoğu federal enstitülerdir ama bazıları özel niteliktedir ve halk kuruluşları olarak tanımlanır. Bunların dişında üniversiteler, öğretmen kuruluşları, siyasi partiler, kiliseler ve ticaret odaları da hizmetiçi kurslar düzenleyebilmektedir (Sözer, 1991; Kıran, 1995; Sağlam, 1999; Arslan, 2000; Aydoğan, 2002; Demirtaş, 2008; ).

Okul yöneticilerinin okulun amaçlarını daha etkili gerçekleştirmeleri için sürekli kendilerini alanlarında yenilemeleri gerekmektedir. Okul yöneticilerinin yeterliklerini geliştirmeleri aynı zamanda eğitim işgörenlerini, öğrencileri, öğrenci velilerini de olumlu yönde etkileyecektir. Öğretmenlerin kendilerini yenilemeleri eğitimin amaçlarının öğrencilerde üst düzeyde gerçekleştirilebilmesi açısından büyük önem taşımaktadır. Alan yazına göre öğretmenler ve okul yöneticileri çeşitli nedenlerle hizmetiçi eğitime ihtiyaç duymaktadır. Yıldız'ın (2006) “Endüstri meslek liselerinde görevli atölye ve laboratuvar öğretmenlerinin hizmetiçi eğitim ihtiyactnın karşılanması" adlı çalışmasına göre atölye ve laboratuvar öğretmenleri en çok mesleki yönlendirmeye yönelik hizmetiçi eğitime ihtiyaç duyarken, yöneticiler öğrencilerin gelişim özelliklerini tanıma, ilgi ve ihtiyaçlarını dikkate almaya yönelik hizmetiçi eğitime ihtiyaç duymaktadır.

Öğretmenlere ve okul yöneticilerine verilen hizmetiçi eğitimin ihtiyaca yönelik olması daha etkili olmasını sağlayacaktır. Gökbulut'un (2006) "Web tabanlı hizmetiçi eğitim planlaması" adlı çalışmasına göre MEB tarafından planlanan hizmetiçi eğitim kurslarının ihtiyaç analizi tam olarak kurum personelinin büyük bir çoğunluğunun görüsü alınmadan yetkililer 
tarafından planlanmaktadır. Düzenlenen hizmetiçi eğitim kursları başlamadan önce eğitimin bir planı ve kurs içeriği ilan edilmemektedir. Düzenlenen kurslar başlamadan önce, devam ederken, kurs sonunda kursun verimliliği ve eğitim veren öğretim görevlileri hakkında değerlendirmeler tam olarak yapılmamakta ve kursiyer görüşlerine başvurulmamaktadır. Kurs merkezlerinde kursa katılan personel zaman zaman donanım yetersizliği ya da personel tutumlarından kaynaklanan problemler yaşanmaktadır. Kursiyerlerin bir kısmı kurslara katılırken tatil amaçlı olarak kurslara katılmaktadırlar.

Hizmetiçi eğitime katılan öğretmenlerin ve okul yöneticilerinin görüşleri sonraki hizmetiçi eğitim etkinliklerinin planlaması ve gerçekleştirilmesi açısından büyük önem taşımaktadır. Sezer'in (2006) "Milli Eğitim Bakanlığına bağh devlet okullarında çalışan psikolojik danışman ve rehber öğretmenlerin hizmetiçi eğitime ilişkin görüşlerinin değerlendirilmesi (İstanbul ili örneği)" adlı çalışmasına göre (a) Hizmet içi eğitim etkinliklerinin süresiyle ilgili olarak psikolojik danışman ve rehber öğretmenlerin görüşleri olumsuzdur ve süre genelde yetersizdir.(b) Psikolojik danışman ve rehber öğretmenlerin uygulanan hizmet içi eğitim etkinliklerinin kapsamıla ilgili görüşleri genelde olumsuzdur.(c) psikolojik danışman ve rehber öğretmenler, hizmet içi eğitim etkinliklerinin uygulanmasında kullanılan yöntem ve tekniklerle ilgili ne olumlu, ne de olumsuz bir görüşe sahip olup, kararsızlıklarını belirtmişlerdir.(d) psikolojik danışman ve rehber öğretmenler, hizmet içi eğitim etkinliklerinin uygulanmasında görevli uygulayıcıların yeterlikleri konusunda kararsız olup, ne olumlu, ne de olumsuz görüşe sahiptirler.(e) Hizmetiçi eğitim etkinliklerinin uygulandığı ortamla ilgili psikolojik danışman ve rehber öğretmen görüşleri alt düzeydedir ve ortam özellikleri yetersizdir.(f) Hizmet içi eğitim etkinliklerinin uygulamaya katkısıyla ilgili olarak psikolojik danışman ve rehber öğretmen görüşleri genelde olumsuzdur. Hizmet içi eğitim etkinliklerinin uygulamaya katkısı düşük olmaktadır. Göçebe'nin (2010) "Milli Ĕ̆itim Bakanlığı merkezi hizmetiçi eğitim kurslarının etkinliği ve yönetim becerilerine katkılar (sağlık meslek lisesi yöneticileri kapsamında bir araştırma)" adlı çalışmasına göre Sağlık Meslek Lisesi yöneticileri, hizmetiçi eğitim programlarının planlanması, amacına göre yürütülmesi ve katılımcılara yarar sağlaması bakımından "çok az"-"kısmen" arası bir değerlendirmede bulunmuşlardır. Bu durum yöneticilerin çoğunluğunun yaş ve kıdem bakımından ileri olmaları, etkinlik sonunda herhangi bir ödülün olmaması, 
hizmetiçi programları konusundaki isteksizliklerini ve konuya olumsuz bir bakış açısıyla bakmalarına neden olmaktadır.

Öğretmenlere ve okul yöneticilerine verilen hizmetiçi eğitimde bilişim teknolojilerinden etkin bir biçimde yararlanmak gerekmektedir. Baran'nın (2008) “Milli Ĕ̆itim Bakanlığı'nın uzaktan hizmetiçi eğitim yöntemiyle bilgisayar eğitimi uygulamasına ilişkin öğretmen görüş ve önerileri" adlı çalışmasına göre öğretmenler "Klasik hizmetiçi eğitim uygulamasına göre uzaktan hizmetiçi eğitim yöntemiyle bilgisayar eğitimi uygulaması daha verimli olmaktadır.

Verilen hizmetiçi eğitim öğretmenlerin ve okul yöneticilerinin verdikleri hizmetin niteliğini olumlu yönde etkilemektedir. Doğan'ın (2009) "Hizmetiçi eğitime katılımın eğitim öğretim sürecine etkisi ile ilgili yönetici ve öğretmen görüşleri" adlı çalışmasına göre yöneticilerin hizmetiçi eğitim faaliyetlerine katılımın eğitim-öğretim sürecine etkisine ilişkin görüşleri genel olarak olumlu olmakla birlikte, katılma düzeylerinin olumlu ifadelerde 'Katılıyorum' düzeyinin üstüne çıkamadığı, olumsuz ifadelerde ise 'Kararsızım' düzeyinde kaldığg görülmektedir ( $X$ minimum=2,67 ve $X$ maksimum=3,92). Öğretmenlerin bakış açısının da yöneticilere benzediği, kendileri için hazırlanmış 30 maddelik ankete verdikleri puanların ortalamalarında ortaya çıkmaktadır. Öğretmenler sadece bir maddede 'Katılmıyorum' düzeyinde puanlamada bulunmuşlardır. Bunun dışında olumlu, olumsuz tüm maddeler 'Kararsızım' ile 'Katılıyorum' düzeyleri arasında puanlama yapılmıştır ( $X$ minimum $=2,43$ ve $X$ maksimum=3,54). Bu nedenle, öğretmenlerin de yöneticiler gibi hizmetiçi eğitimlerin faydası konusunda şüpheleri olduğu düşünülebilir. Akkaya' nın (2010) “Okul yöneticilerinin bilgi teknolojileri becerilerinin ve tutumlarının geliştirilmesi: Bir hizmetiçi eğitim uygulaması" adlı çalışmasına göre hizmetiçi eğitimler, yöneticiler tarafından nitelikli bulunmuş ve olumlu olarak değerlendirilmiştir. Ancak yöneticilerin hizmetiçi eğitimin değerlendirmelerini yaptıkları açık uçlu maddede, çoğu yönetici verilen eğitimin zamanlamasının doğru olmadığını belirtmiştir. Yağı'ın (2011) "Hizmetiçi eğitim uygulamalarmm öğrenen okula etkisi ile ilgili öğretmen görüşleri" adlı çalışmasına göre öğretmenlerin, hizmetiçi eğitimin öğrenen okula etkisine ilişkin önermelere katılım düzeylerine ait ortalama değerlerinin 2,096 ile 1,443 arasında değişiyor oluşu öğretmenlerin hizmetiçi eğitimin öğrenen okula etkisini araştırmak amacıyla yapılan önermelere olumlu yanıt verdikleri görülmektedir. Yani öğretmenlerin çoğunluğu 
hizmetiçi eğitimin öğrenen okula etkisini olumlu bir şekilde etkilediklerine inanmaktadırlar.

Bu çalışmada okulöncesi, ilköğretim, ortaöğretim okul yöneticileri ve bu okullarda görev yapan öğretmenlere verilen hizmetiçi eğitim irdelenmiştir. İrdelemede Denizli İl Milli Eğitim Müdürlüğünün 2011-2012 eğitim-öğretim yılında okulöncesi, ilköğretim, ortaöğretim okul yöneticileri ve bu okullarda görev yapan öğretmenlere yönelik olarak düzenlediği hizmet içi eğitimle ilgili veriler kullanılmıştır.

\section{Yöntem}

Araştırmada genel tarama modeli kullanılmıştır. Tarama modeli, geçmişte ya da halen var olan bir durumu var olduğu şekliyle betimlemeyi amaçlayan araştırma yaklaşımıdır (Karasar, 2007). Araştırmada çalışma grubunu, Denizli İl Milli Eğitim Müdürlügünün 2011-2012 Eğitim-öğretim yılında (1 Eylül 2011 - 30 Haziran 2012 tarihleri arasında) gerçekleştirdiği hizmetiçi eğitim etkinliklerine katılan okulöncesi, ilköğretim, ortaöğretim okul yöneticileri ve bu okullarda görev yapan öğretmenler oluşturmaktadır. Öğretmenlere ve okul yöneticilerine verilen hizmetiçi eğitim etkinlikleri, yıllık olarak Milli Eğitim Bakanlığı ve İl Milli Eğitim Müdürlüğü işbirliğiyle planlanmakta ve uygulanmaktadır. Bu çalışmada 2011-2012 eğitim-öğretim yılı esas alındığından 1 Eylül-2011 ve 30 Haziran 2012 tarihleri arasında Denizli İl Milli Eğitim Müdürlügünün hizmet içi eğitim etkinlikleri esas alınmıştır. Denizli İl Milli Eğitim Müdürlüğünün gerçekleştirdiği hizmetiçi eğitim etkinlikleri ve etkinliklere katılan okulöncesi, ilköğretim, ortaöğretim okul yöneticileri ve bu okullarda görev yapan öğretmenlerle ilgili veriler Denizli İl Milli Eğitim Müdürlüğü Hizmetiçi Eğitim biriminden elde edilmiştir. Denizli İl Milli Eğitim Müdürlüğü Hizmetiçi Eğitim biriminden elde edilen veriler "gerçekleştirilen ve gerçekleştirilemeyen", "il ve ilçe merkezinde gerçekleştirilen", "katılanların sayısı", "etkinliklerinin düzenlendiği kesim", "öğretmenlere verilen hizmet içi eğitim etkinliklerinin niteliği" ve "okul yöneticilerine verilen hizmet içi eğitim etkinliklerinin niteliği" kategorilerinde çözümlenmiştir.

\section{Bulgular ve Yorum}

Denizli İl Milli Eğitim Müdürlüğünün gerçekleştirdiği hizmetiçi eğitim etkinlikleri ve etkinliklere katılan okulöncesi, ilköğretim, ortaöğretim okul yöneticileri ve bu okullarda görev yapan öğretmenlerle ilgili Denizli İl 
Uşak Üniversitesi Sosyal Bilimler Dergisi

$2013,6 / 4$

A. R. ERDEM, S. ŞIMMŞEK

Milli Eğitim Müdürlüğü Hizmetiçi Eğitim biriminden elde edilen veriler çalışmanın amacı doğrultusunda analiz edilmiş ve yorumlanmıştır.

Tablo 1: Denizli İl Milli Ĕ̆gitim Müdürlü̆̆̈̈ tarafindan 2011-2012 eğitim-öğretim yılında gerçekleştirilen ve gerçekleştirilemeyen hizmet içi eğitim etkinlikleri

\begin{tabular}{lcllllll}
\hline 1 Eylül - 31 Aralık 2011 & \multicolumn{4}{c}{ 1 Ocak - 30 Haziran 2012 } \\
\hline $\begin{array}{l}\text { Gerçek } \\
\text { leştirilen }\end{array}$ & $\%$ & $\begin{array}{l}\text { Gerçekleştiri } \\
\text { lemeyen }\end{array}$ & $\%$ & $\begin{array}{l}\text { Gerçekleş } \\
\text { tirilen }\end{array}$ & $\%$ & $\begin{array}{l}\text { Gerçekleşti } \\
\text { rilemeyen }\end{array}$ & $\%$ \\
\hline 41 & 11 & 49 & 13 & 205 & 52 & 96 & 24 \\
\hline
\end{tabular}

Kaynak: Denizli MEM 2011 yılı mahalli hizmetiçi eğitim planı, Denizli Milli Eğitim Müdürlüğü Hizmetiçi eğitim şubesi

Denizli MEM 2012 yılı mahalli hizmetiçi eğitim planı, Denizli Milli Eğitim Müdürlüğü Hizmetiçi eğitim şubesi

Denizli İl Milli Eğitim Müdürlüğü tarafından 2011-2012 eğitimöğretim yılında öğretmenlere ve okul yöneticilerine yönelik hizmetiçi eğitim için gerçekleştirilen etkinlik sayısı 246 (\% 63) gerçekleştirilemeyen etkinlik sayısı ise 137 (\% 37) dir. Bu sonuca göre Denizli İl Milli Eğitim Müdürlüğü tarafından 2011-2012 eğitim-öğretim yılında öğretmenlere ve okul yöneticilerine yönelik hizmetiçi eğitim etkinlikleri büyük oranda gerçekleştirdiği anlaşılmaktadır.

Tablo 2: Denizli Il Milli Eğitim Müdürlüğ̈̈ tarafindan 2011-2012 eğitim-öğretim yılında il ve ilçe merkezinde gerçekleştirilen hizmet içi eğitim etkinlikleri

\begin{tabular}{llllllll}
\hline 1 Eylül & -31 Aralık 2011 & \multicolumn{4}{c}{ 1 Ocak- 30 Haziran 2012 } & \\
\hline $\begin{array}{l}\text { İl } \\
\text { merkezi }\end{array}$ & $\%$ & İlçe merkezi & $\%$ & $\begin{array}{l}\text { İl } \\
\text { merkezi }\end{array}$ & $\begin{array}{l}\text { İlçe } \\
\text { merkezi }\end{array}$ & $\%$ \\
\hline 38 & 16 & 3 & 1 & 101 & 41 & 104 & 42 \\
\hline
\end{tabular}

Kaynak: Denizli MEM 2011 yılı mahalli hizmetiçi eğitim planı, Denizli Milli Eğitim Müdürlüğü Hizmetiçi eğitim şubesi

Denizli MEM 2012 yılı mahalli hizmetiçi eğitim planı, Denizli Milli Eğitim Müdürlüğü Hizmetiçi eğitim şubesi

Denizli İl Milli Eğitim Müdürlüğü tarafından 2011-2012 eğitimöğretim yılında öğretmenlere ve okul yöneticilerine yönelik hizmetiçi eğitim etkinliklerinin 139'u ( $\%$ 57) il, $1077^{\prime} \mathrm{i} \quad\left(\begin{array}{l}\% \\ \%\end{array}\right)$ ilçe merkezinde gerçekleştirilmiştir. Bu sonuca göre Denizli ìl Milli Eğitim Müdürlüğü 
Uşak Üniversitesi Sosyal Bilimler Dergisi

$2013,6 / 4$

A. R. ERDEM, S. ŞIMMŞEK

tarafından 2011-2012 eğitim-öğretim yılında öğretmenlere ve okul yöneticilerine yönelik hizmetiçi eğitim etkinlikleri yarı yarıya il ve ilçe merkezlerinde gerçekleştirilmiştir. İlçelerde görev yapan öğretmen ve eğitim yöneticilere görev yaptıkları yerlerde hizmet içi eğitim verildiğini göstermesi açısından bu sonuç oldukça önemlidir.

Tablo 3: Denizli Ill Milli Ĕ̆itim Müdürlüğ̈̈ tarafından 2011-2012 eğitim-öğretim yılında gerçekleştirilen hizmet içi eğitim etkinliklerine katılanların sayısı

\begin{tabular}{lcccccccccc}
\hline ZAMAN & \multicolumn{1}{l}{ KATILIMCI SAYISI } & & & & & & \\
& $\mathbf{1 -}$ & $\mathbf{\%}$ & $\mathbf{3 1 -}$ & $\mathbf{\%}$ & $\mathbf{6 1 -}$ & $\mathbf{\%}$ & $\mathbf{9 1 -}$ & $\mathbf{\%}$ & $\mathbf{1 2 1 +}$ & $\mathbf{9}$ \\
& $\mathbf{3 0}$ & & $\mathbf{6 0}$ & & $\mathbf{9 0}$ & & $\mathbf{1 2 0}$ & & & \\
& 35 & 14 & 6 & 2 & & & & & & \\
\hline $\begin{array}{l}1 \text { Eylül - } \\
31 \text { Aralık 2011 }\end{array}$ & & & & & & & & & & \\
$\begin{array}{l}1 \text { Ocak- } \\
30 \text { Haziran 2012 }\end{array}$ & 132 & 54 & 36 & 15 & 12 & 5 & 10 & 4 & 15 & 6 \\
\hline
\end{tabular}

Kaynak: Denizli MEM 2011 yılı mahalli hizmetiçi eğitim planı, Denizli Milli Eğitim Müdürlügü Hizmetiçi eğitim şubesi

Denizli MEM 2012 yılı mahalli hizmetiçi eğitim planı, Denizli Milli Eğitim Müdürlüğü Hizmetiçi eğitim şubesi

Denizli İl Milli Eğitim Müdürlüğü tarafından 2011-2012 eğitimöğretim yılında öğretmenlere ve okul yöneticilerine yönelik hizmetiçi eğitim etkinliklerine katılanların sayısı 167 etkinlikte 1-30 kişi (\% 68) arasında değişmektedir. Eğer hizmetiçi eğitim 30 katılımcıdan fazla sayıda tek bir merkezde yapılıyorsa hizmetiçi eğitime katılanların sayısı artıkça etkililik azalmaktadır. Hizmetiçi eğitimin yapıldığı merkezde düzenlenen hizmetiçi eğitimin etkililiği de göz önüne alındığında katılımcıların sayısının 30 ‘u aşmaması idealdir.

Tablo 4: Denizli Il Milli Eğitim Müdürlüğ̈̈ tarafindan 2011-2012 eğitim-öğretim yılında gerçekleştirilen hizmet içi eğitim etkinliklerinin düzenlendiği kesim

ZAMAN HİZMETIÇİ EĞİTIMIN DÜZENLENDİĞİ KESİM

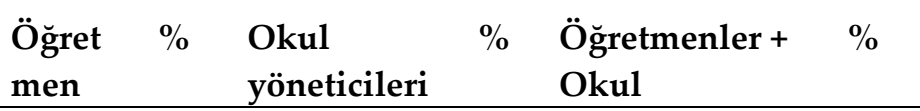


Uşak Üniversitesi Sosyal Bilimler Dergisi

$2013,6 / 4$

A. R. ERDEM, S. ŞIMMŞEK

\begin{tabular}{|c|c|c|c|c|c|c|}
\hline \multicolumn{4}{|c|}{ ler } & \multicolumn{3}{|c|}{ yöneticileri } \\
\hline $\begin{array}{l}1 \text { Eylül - } \\
31 \text { Aralık } 2011\end{array}$ & 19 & 8 & 3 & 1 & 19 & 8 \\
\hline $\begin{array}{l}1 \text { Ocak- } \\
30 \text { Haziran } 2012\end{array}$ & 53 & 22 & 56 & 23 & 96 & 38 \\
\hline
\end{tabular}

Kaynak: Denizli MEM 2011 yılı mahalli hizmetiçi eğitim planı, Denizli Milli Eğitim Müdürlüğü Hizmetiçi eğitim şubesi

Denizli MEM 2012 yılı mahalli hizmetiçi eğitim planı, Denizli Milli Eğitim Müdürlüğü Hizmetiçi eğitim şubesi

Denizli İl Milli Eğitim Müdürlüğü tarafından 2011-2012 eğitimöğretim yılında öğretmenlere ve okul yöneticilerine yönelik hizmetiçi eğitim etkinliklerinin $115^{\prime}$ i (\% 46) öğretmen ve okul yöneticilerine, 72 'si (\% 30) öğretmenlere ve 59`u (\% 24) okul yöneticilerine verilmiştir. Okulda eğitimin amaçlarını, öğretmenler ve okul yöneticileri birlikte gerçekleştirdiklerinden dolayı öğretmen ve okul yöneticilerinin birlikte aldıkları hizmetiçi eğitim etkinliklerinin sayısının fazla olması eğitimin amaçlarının okulda daha etkili olarak gerçekleştirilmesini sağlayabilir.

Tablo 5: Denizli İl Milli Eğitim Müdürlüğ̈̈ tarafindan 2011-2012 eğitim-öğretim yılında öğretmenlere verilen hizmet içi eğitim etkinliklerinin niteliği

\begin{tabular}{|c|c|c|c|c|}
\hline \multirow[t]{2}{*}{ ZAMAN } & \multicolumn{4}{|c|}{$\begin{array}{l}\text { ÖĞRETMENLERE VERİLEN HİZMETİÇİ EĞİTIMİN } \\
\text { NİTELİĞİ }\end{array}$} \\
\hline & $\begin{array}{l}\text { Özel alan } \\
\text { yeterliliği }\end{array}$ & $\%$ & $\begin{array}{l}\text { Genel yeterlikler } \\
\text { (Pedagojik } \\
\text { Formasyon) }\end{array}$ & $\%$ \\
\hline $\begin{array}{l}1 \text { Eylül - } \\
31 \text { Aralık } 2011\end{array}$ & 4 & 6 & 15 & 20 \\
\hline $\begin{array}{l}1 \text { Ocak- } \\
30 \text { Haziran } 2012\end{array}$ & 5 & 7 & 48 & 67 \\
\hline
\end{tabular}

Kaynak: Denizli MEM 2011 yılı mahalli hizmetiçi eğitim planı, Denizli Milli Eğitim Müdürlüğü Hizmetiçi eğitim şubesi

Denizli MEM 2012 yılı mahalli hizmetiçi eğitim planı, Denizli Milli Eğitim Müdürlüğü Hizmetiçi eğitim şubesi 
Denizli İl Milli Eğitim Müdürlüğü tarafından 2011-2012 eğitimöğretim yılında öğretmenlere verilen hizmetiçi eğitim etkinliklerinin 9'u (\% 13) özel alan yeterliğine, 63’ ü (\% 87) genel yeterliklere yönelik verilmiştir. Öğretmenlere verilen hizmetiçi eğitimde "genel yeterlikler" e yoğunlaşıldığı görülmektedir.

Tablo 6: Denizli Ill Milli Ĕ̆itim Müdürlüğ̈̈ tarafından 2011-2012 eğitim-öğretim yılında okul yöneticilerine verilen hizmet içi eğitim etkinliklerinin niteliği

\section{ZAMAN OKUL YÖNETICİLERINE VERILEN HIZZMETIÇİ EĞİTIMINN NITELIGĞí}

\begin{tabular}{lllllll} 
& $\begin{array}{l}\text { Teknik } \\
\text { yeterlik }\end{array}$ & $\%$ & $\begin{array}{l}\text { İnsanc1 } \\
\text { yeterlik }\end{array}$ & $\%$ & $\begin{array}{l}\text { Kavramsal } \\
\text { yeterlik }\end{array}$ & $\%$ \\
\hline 1 Eylül - & 1 & 2 & 1 & 2 & 1 & 2
\end{tabular}

31 Aralık 2011

$\begin{array}{lllllll}1 \text { Ocak- } & 28 & 47 & 18 & 30 & 10 & 17\end{array}$

30 Haziran 2012

Kaynak: Denizli MEM 2011 yılı mahalli hizmetiçi eğitim planı, Denizli Milli Eğitim Müdürlüğü Hizmetiçi eğitim şubesi

Denizli MEM 2012 yılı mahalli hizmetiçi eğitim planı, Denizli Milli Eğitim Müdürlüğü Hizmetiçi eğitim şubesi

Denizli İl Milli Eğitim Müdürlüğü tarafından 2011-2012 eğitimöğretim yılında okul yöneticilerine verilen hizmetiçi eğitim etkinliklerinin $29^{\prime}$ u (\% 49) teknik yeterliğe, 19' u (\% 32) insancil yeterliğe ve 11'i (\% 19) kavramsal yeterliğe yönelik verilmiştir. Okul yöneticilerine verilen hizmetiçi eğitimde "teknik yeterlikler" e yoğunlaşıldığı görülmektedir.

\section{Sonuç ve Öneriler}

Çalışmayla ilgili elde edilen sonuçlar incelendiğinde, Denizli İl Milli Eğitim Müdürlüğünün 2011-2012 eğitim-öğretim yılında okulöncesi, ilköğretim, ortaöğretim okul yöneticileri ve bu okullarda görev yapan öğretmenlere yönelik planlanan hizmetiçi eğitim etkinliklerinin \% 63'ü gerçekleştirilmiş, \% 57'si il merkezinde yapılmıştır. Etkinliklerin \% 68 'sine katılan katılımcıların sayısı 1-30 kişi arasında değişmekte olup, \% 46'sı öğretmen ve yöneticilere yönelik verilmiştir. Öğretmenlere verilen 
etkinliklerin \% 87'si "genel yeterlikler" e, yöneticilere verilenlerin etkinliklerin \% 49'u "teknik yeterlik" e yöneliktir. Elde edilen bulgulara göre şunlar önerilebilir:

1) Denizli İl Milli Eğitim Müdürlüğü tarafından 2011-2012 eğitim-öğretim yılında öğretmenlere ve okul yöneticilerine yönelik hizmetiçi eğitim etkinliklerinin 139'u (\% 57) il, 107'si ( $\%$ 43) ilçe merkezinde gerçekleştirilmiştir. İlçe merkezlerinde hizmetiçi eğitimin gerçekleştirilmesine daha fazla öncelik verilebilir.

2) Denizli İl Milli Eğitim Müdürlüğü tarafından 2011-2012 eğitim-öğretim yılında öğretmenlere ve okul yöneticilerine yönelik hizmetiçi eğitim etkinliklerinin \% 4'ü 91-120, \% 6'sı 121+ katılımcı ile gerçekleştirilmiştir. Hizmetiçi eğitimin yapıldığı merkezde düzenlenen hizmetiçi eğitimin etkililiği de göz önüne alınarak katılımcıların sayısının 30 'u aşmaması sağlanabilir.

3) Denizli İl Milli Eğitim Müdürlüğü tarafından 2011-2012 eğitim-öğretim yılında öğretmenlere verilen hizmetiçi eğitim etkinliklerinin 9'u (\% 13) özel alan yeterliğine, 63' ü (\% 87) genel yeterliklere yönelik verilmiştir. Öğretmenlere verilen hizmetiçi eğitimlerin öncelikli olarak özel alan yeterliklerinin geliştirilmesine yönelik olabilir.

4) Denizli İl Milli Eğitim Müdürlüğü tarafından 2011-2012 eğitim-öğretim yllında okul yöneticilerine verilen hizmetiçi eğitim etkinliklerinin $29^{\prime} \mathrm{u}$ (\% 49) teknik yeterliğe, 19' u (\% 32) insancil yeterliğe ve $11^{\prime} \mathrm{i}$ (\% 19) kavramsal yeterliğe yönelik verilmiştir. Okul yöneticilerine yönelik verilen hizmetiçi eğitimlerin öncelikli olarak "insancll" ve "kavramsal" yeterliklerin geliştirilmesine yönelik olabilir.

\section{Kaynaklar}

Akkaya, E. A. (2010) Okul yöneticilerinin bilgi teknolojileri becerilerinin ve tutumlarının geliştirilmesi: Bir hizmetiçi eğitim uygulaması, Yayınlanmamış Yüksek Lisans Tezi, Akdeniz Üniversitesi Sosyal Bilimler Enstitüsü, Antalya

Arseven, İ. (2009) Bağlam ve süreç boyutlarında bir hizmetiçi eğitim programının değerlendirilmesi, Yayınlanmamış Doktora Tezi, Hacettepe Üniversitesi Sosyal Bilimler Enstitüsü, Ankara

Arslan, D. (2000). Sınıföğretmenlerinin hizmetiçi eğitimi ve sorunlarının 
çözümüne yönelik bir model (Kütahya Örneği).Yayınlanmamış Yüksek Lisans Tezi, Dumlupınar Üniversitesi Sosyal Bilimler Enstitüsü, Kütahya

Aydın, D. (2008) Öğretmenlerin, yöneticiler tarafından hizmetiçi eğitim programıyla desteklenmesi sonucunda kazandiklar bilgi ve becerileri eğitime yansıtma düzeylerinin incelenmesi (İstanbul Beykoz ilçesi örneği), Yayınlanmamış Yüksek Lisans Tezi, Yeditepe Üniversitesi, Sosyal Bilimler Enstitüsü, İstanbul

Aydoğan, İ. (2002). MEB ilköğretim okullar yönetici ve öğretmenlerinin personel geliştirmeye ilişkin görüşleri (Kayseri ili örneği). Yayınlanmamış Doktora Tezi, Ankara Üniversitesi, Eğitim Bilimleri Enstitüsü, Ankara

Azar, A. ve Karaali, Ş., (2004). Fizik öğretmenlerinin hizmet içi eğitim ihtiyaçları. Milli Eğitim Dergisi, 162, 279-295.

Baran, F. (2008) Milli Eğitim Bakanlığı'nın uzaktan hizmetiçi eğitim yöntemiyle bilgisayar eğitimi uygulamasına ilişkin öğretmen görüş ve önerileri, Yayınlanmamış Yüksek Lisans Tezi, Yeditepe Üniversitesi, Sosyal Bilimler Enstitüsü, İstanbul

Budak, Y., (1998). Eğitimde toplam kalite yönetimi açısından öğretmenlere yönelik hizmet içi eğitim ihtiyaçları ve programlarına bir yaklaşım. Milli Ĕ̆itim Dergisi, 140, 35-38.

Can, E. (2011) Türkiye'de kamu personelinin hizmetiçi eğitiminde biliş̧im teknolojilerinin rolü, Yayınlanmamış Yüksek Lisans Tezi, Dokuz Eylül Üniversitesi, Sosyal Bilimler Enstitüsü, İzmir

Çatmalı, M. (2006) Gelecek için eğitim" hizmetiçi eğitim kursunun değerlendirilmesi, Yayınlanmamış Yüksek Lisans Tezi, Balıkesir Üniversitesi, Fen Bilimleri Enstitüsü, Balıkesir

Demirtaş, T. Y. (2008) İlköğretim okulları öğretmenlerinin hizmetiçi eğitim ihtiyaçları ile kurum içi iletişim algıları arasındaki ilişkinin değerlendirilmesi, Yayınlanmamış Yüksek Lisans Tezi, Yeditepe Üniversitesi, Sosyal Bilimler Enstitüsü, İstanbul 
Uşak Üniversitesi Sosyal Bilimler Dergisi

$2013,6 / 4$

A. R. ERDEM, S. ŞIMŞEK

Denizli MEM 2011 yılı mahalli hizmetiçi eğitim planı, Denizli Milli Eğitim Müdürlüğü Hizmetiçi eğitim şubesi Denizli MEM 2012 y1lı mahalli hizmetiçi eğitim planı, Denizli Milli Eğitim Müdürlüğü Hizmetiçi eğitim şubesi

Doğan, O. (2009) Hizmetiçi eğitime katılımın eğitim öğretim sürecine etkisi ile ilgili yönetici ve öğretmen görüşleri, Yayınlanmamış Yüksek Lisans Tezi, Maltepe Üniversitesi, Sosyal Bilimler Enstitüsü, İstanbul

Erişen, Y., (1998). Öğretmenlere yönelik hizmet içi eğitim programları geliştirmede eğitim ihtiyacı belirleme süreci. Milli Eğitim Dergisi, $140,39-43$

Göçebe, H. (2010) MEB merkezi hizmetiçi eğitim kurslarının etkinliği ve yönetim becerilerine katkıları (sağlık meslek lisesi yöneticileri kapsamında bir araştırma), Yayınlanmamış Yüksek Lisans Tezi, Yeditepe Üniversitesi, Sosyal Bilimler Enstitüsü, İstanbul

Gökbulut, B. (2006) Web tabanlı hizmetiçi eğitim planlaması, Yayınlanmamış Yüksek Lisans Tezi, Gazi Üniversitesi, Fen Bilimleri Enstitüsü, Ankara

Karaküçük, S. (1987). Öğretmenlerin hizmet içi eğitimlerinde üniversitelerin fonksiyonları, Gazi Üniversitesi Eğitim Fakültesi Dergisi, 31, 309-315.

Karasar, N. (2007). Bilimsel Araştırma Yöntemi, 17. Baskı, Nobel Yayınları, Ankara.

Kıran, A. (1995). Fransız öğretim sisteminde öğretmen yetiştirme, Hacettepe Üniversitesi Ĕ̆itim Fakültesi Dergisi (11), 163-169

Saban, A., (2000). Hizmet içi eğitimde yeni yaklaşımlar. Milli Ĕğitim Dergisi, $145,25-30$.

Sağlam, M. (1999). Avrupa ülkelerinin eğitim sistemleri, Eskişehir.

Seferoğlu, S. S., (2005). Sınıf öğretmenlerinin kendi meslekî gelişimleriyle 
ilgili görüşleri, beklentiler ve önerileri. İnternetten 30.09.2012'de http://dhgm.meb.gov.tr/yayimlar/dergiler/Milli Egitim Dergisi/149/ seferoglu.htm, adresinden indirilmiştir.

Sezer, E. (2006) Milli Ĕ̆itim Bakanlı̆̆ına bağlı devlet okullarında çalışan psikolojik danışman ve rehber öğretmenlerin hizmetiçi eğitime ilişkin görüşlerinin değerlendirilmesi (İstanbul ili örneği), Yayınlanmamış Yüksek Lisans Tezi, Yeditepe Üniversitesi, Sosyal Bilimler Enstitüsü, İstanbul

Sözer, E. (1991). Türk üniversitelerinde öğretmen yetiştirme sistemlerinin öğretmenlik davranışlarını kazandırma yönünden etkililiği, Eskişehir.

Taşc1, F. (2003) Hizmetiçi eğitimde interaktif yöntemlerin etkinliğinin değerlendirilmesi, Yayınlanmamış Yüksek Lisans Tezi, Marmara Üniversitesi, Sağlık Bilimleri Enstitüsü, İstanbul

Uçar, R. \& İpek, C. (2006) İlköğretim okullarında görev yapan yönetici ve öğretmenlerin MEB hizmet içi eğitim uygulamalarına ilişkin görüşleri, Yüzüncü Yal Üniversitesi, Eğitim Fakültesi Dergisi, 3 (1), 3453

Yağız, L. (2011) Hizmetiçi eğitim uygulamalarının öğrenen okula etkisi ile ilgili öğretmen görü̈sleri, Yayınlanmamış Yüksek Lisans Tezi, Yeditepe Üniversitesi, Sosyal Bilimler Enstitüsü, İstanbul

Yalın H. (2001) Hizmetiçi eğitim programlarının değerlendirilmesi", Milli Eğitim Dergisi, 150, 58-68

Yıldırım, F. (2007) Öğretmenlerin hizmetiçi eğitimine yönelik uzaktan eğitim platformu tasarımı, Yayınlanmamış Yüksek Lisans Tezi, Sakarya Üniversitesi, Fen Bilimleri Enstitüsü, Sakarya

Yıldız, C. (2006) Endüstri meslek liselerinde görevli atölye ve laboratuvar öğretmenlerinin hizmetiçi eğitim ihtiyacının karşılanmasl, Yayınlanmamış Yüksek Lisans Tezi, Yeditepe Üniversitesi, Sosyal Bilimler Enstitüsü, İstanbul

Yüksel, Ö. (1998) İnsan kaynakları yönetimi, Gazi Kitabevi, Ankara 